\title{
Роберт Херманн
}

\section{ЦЕЛУЮ РУКИ ВАШЕМУ ВЕЛИЧЕСТВУ \\ Об одном несостоявшемся жесте}

\section{'I BEG LEAVE TO KISS YOUR MAJESTY'S HAND!' About a Gesture Which Never Happened}

On May 21, 1849, the Austrian Emperor Francis Joseph I and the Russian Tsar Nicholas I met in Warsaw. At that time, the agreement according to which the Russian tsar would send 200,000 soldiers to defeat the Hungarian war of independence was finalized.

Such a force alone was able to decide the war. Emperor Francis Joseph I was undoubtedly grateful to Tsar Nicholas. According to several historical works, he also expressed his gratitude with a theatrical gesture: he knelt in front of the tsar on the balcony of Lazienki Palace in Warsaw and kissed his hand.

The study looks at whether this hand kiss really happened or whether we are dealing with a later legend. This is because this hand kiss has no trace in either the Austrian or Russian literature, it only occurs in Hungarian works.

The story is first mentioned in one of the works of historian Dávid Angyal, and Angyal refers to a book review by Antal Hodinka. Hodinka seems to have misunderstood a Russian book he had previously reviewed, and Angyal did not verify Hodinka's details. Since Dávid Angyal was a very respectable historian, the authors of later works took this data from him on trust.

The interesting thing about the case is that we have data on a similar hand kiss from May 1849 - except that it didn't happened between Franz Joseph I and Nicholas I. On May 1, 1849, the Austrian Prime Minister Felix Schwarzenberg wrote in a letter on May 1 requesting immediate military aid from the Commander-in-Chief of the Russian troops in Poland, Field Marshall Paskevich. Austrian Lieutenant General Bernhard Caboga, who had delivered the letter, also read the contents of the letter aloud, then knelt down and kissed Paskevich's hand and tearfully begged him to save Austria. Probably this story was transformed in the memory of Antal Hodinka, and thus the legend about the hand kiss of Francis Joseph emerged.

Keywords: Hungarian War of Independence in 1848-49, Russian intervention in Hungary in 1849, Francis Joseph I, Nicholas I, Paskevich, historical legends, Bernhard Caboga

Róbert Hermann - D.Sc. in History, Professor, Institute of History, Faculty of Humanities and Social Sciences, Károli Gáspár University of the Reformed Church in Hungary (Hungary, Budapest, 1146 Dózsa György út 25.). ORCID: https://orcid.org/0000-0003-2203-9427 E-mail: hermann.robert@kre.hu 
21 мая 1849 г. в Варшаве произошла встреча австрийского императора Франца Иосифа I с русским царем Николаем І. На ней была окончательно оформлена конвенция, согласно которой русский царь должен был оказать военную помощь австрийскому императору для подавления ширившегося «венгерского бунта», иначе говоря, борьбы за независимость Венгрии, которая грозила самому существованию Австрии.

В Венгрии большинство политиков с марта 1848 г. ясно понимало, что вооруженная интервенция «Северного колосса», царской России, может последовать в любое время. Канцлер дёрдь Аппони уже в начале марта 1848 г. предупреждал об этом Иштвана Сечени, такую возможность имел в виду и Кошут, когда в своей речи, произнесенной 3 марта, отметил, что «если бы в Вене был человек, который ради своей недолговечной власти и в ущерб династии подумывал бы о союзе с абсолютистскими державами, то ему следовало бы задуматься над тем, что есть державы, более опасные в качестве друзей, чем в качестве врагов». После оккупации русскими войсками Дунайских княжеств в июне 1848 г. правительство Баттяни чуть ли не первым делом запросило русского посла в Вене о причинах этого шага, но получило успокоительный ответ: этот шаг был необходим для поддержания внутреннего спокойствия в империи, и Россия «желает поддерживать с венгерской нацией добрососедское согласие и не сделает в отношении Венгии никаких враждебных шагов до тех пор, пока не увидит на лоне венгерской нации каких-либо скоплений людей и оружия, в которых она почувствует угрозу для себя».2

Царя Николая больше интересовали события, связанные с проблемой немецкого единства, нежели с положением в Венгрии. Он с удовлетворением воспринимал вести об успехах императорских королевских войск осенью и зимой 1848 г. Мысль о возможности русского вмешательства впервые возникла у него тогда, когда он получил сообщения о том, что Бем может вторгнуться в Буковину. С этого момента в своих письмах он все чаще занимался перспективами военных действий в Венгрии и возможностью интервенции. ${ }^{3}$

1 Kossuth Lajos összes munkái. XI. Kossuth Lajos az utolsó rendi országgyülésen (Budapest: Akadémiai Kiadó, 1951), 624.

2 См.: Речь Кошута 11 июля 1848 г. Опубликована в кн.: Kossuth Lajos összes munkái. XII. k. Kossuth Lajos az első magyar felelős minisztériumban (Budapest: Akadémiai Kiadó, 1957), 433-434.

3 A. P. SCSERBATov, Paszkevics Magyarországon (Budapest: Európa Könyvkiadó, 1984), 179-260. 
В соответствии с Мюнхенгрецкой конвенцией 1833 г. Австрия могла рассчитывать на помощь русской армии, однако австрийское правительство из соображений престижа не спешило воспользоваться этой помощью. Русская интервенция была чревата и дипломатическими последствиями, поскольку без согласия Англии и Франции вмешательство содержало в себе и угрозу широкого вооруженного конфликта. Оккупация Дунайских княжеств и без того беспокоила британскую дипломатию. После провала русской интервенции в Трансильвании Кошут и Бем надеялись на то, что Англия и Франция предпримут дипломатические шаги, чтобы предотвратить повторение подобной попытки. ${ }^{4}$

К концу марта 1849 г. становилось все очевиднее, что находившаяся в Венгрии императорская королевская армия не способна в одиночку подавить венгерский «бунт». И в Вене, и в Буде все чаще говорили о вмешательстве России. Поначалу в Вене хотели увеличить численность вооруженых сил в Венгрии посредством вывода императорских королевских войск из Буковины и Галиции, где их должны были заменить русские оккупационные части. В свою очередь, Виндишгрец уже 24 марта считал необходимым введение в Венгрию по крайней мере 50000 русских солдат. Это предложение сыграло определенную роль в подрыве позиций герцога, но после успешного весеннего похода большинство политиков и военных тоже уже не видело иного решения. Оно получило и поддержку западных великих держав. ${ }^{5}$ Переговоры о подготовке интервенции начались уже в конце марта, а 21 апреля была направлена официальная просьба о помощи. 1 мая Франц Иосиф І обратился по этому вопросу к царю Николаю с собственноручным письмом. ${ }^{6}$

Оставалось еще выяснить детали операции. Австрийская сторона выступила с инициативой посылки вспомогательных отрядов численностью в несколько десятков тысяч человек, подчиненных

4 HoRváth Jenő, „Bem tábornok és a bukaresti külképviseletek 1849 március-júniusban”, Hadtörténelmi Közlemények (1927): 375-386; V. WALDAPFEL ESZTER, A független magyar külpolitika 1848-1849. (Budapest, 1962), 148-192.

5 Hugo KeRchnawe, Feldmarschall Fürst Windisch-Graetz und die Russenhilfe 1848. (Beiträge für die Geschichte der Jahre, 1848-1849. Heft 3). (Innsbruck, 1930). DOI: 10.7767/ miog.1929.43.34.325

6 CM.: ANDICS ERZsÉBET, A Habsburgok és Romanovok szövetsége (Budapest: Akadémiai Kiadó, 1961), 361-362, 373-374. Нужно отметить, что в книге Андич даже не упоминается варшавская встреча двух монархов. 
австрийскому командованию. Однако Николай I считал, что должен выставить сильную армию, которая смогла бы и в одиночку подавить революцию. Поэтому он принял решение направить в Венгрию около 200000 солдат, приведя в готовность еще 80000 человек. Ранее столь многочисленные русские вооруженные силы не принимали участия ни в одной европейской войне XIX века. ${ }^{7}$ Царь был готов задействовать в Венгрии примерно треть всей своей армии.

Одновременно с этим Россия обеспечила военную акцию и с дипломатической точки зрения. 1 мая в Балта-Лимане она заключила с Турцией конвенцию, которая обеспечила России равноправную роль в Дунайских княжествах. Эта конвенция обеспокоила британских политиков, которые, однако, были вполне удовлетворены походом для спасения Габсбургскоймонархии. Англии было важно воспрепятствовать продвижению России на Балканах, а для этого она нуждалась в сильной Австрии. «Кончайте с ними побыстрее», - сказал министр иностранных дел Пальмерстон русскому послу, интересовавшемуся британской реакцией. Иначе говоря, он считал важным, чтобы по окончании войны русская армия как можно скорее вернулась в границы России.

Такой военный контингент мог и сам по себе решить судьбу освободительной войны в Венгрии. Император Франц Иосиф I, несомненно, должен был быть признателен царю Николаю за эту братскую помощь. Во многих исторических работах говорится о том, что эту признательность он выразил театральным жестом - опустился перед царем на колени и поцеловал ему руку на балконе Лазенковского дворца в Варшаве.

Первым венгерским историком, у которого мы находим этот эпизод, был Давид Андял, опубликовавший в 1942 г. книгу Az ifjú Ferenc József (Молодость Франца Иосифа). Этот автор, ранее известный скорее своими занятиями венгерской историей XVI-XVII вв., провел серьезную работу по сбору источников в венских архивах, прежде всего в бумагах «Домашнего, придворного и государственного архива», и отлично знал австрийскую специальную литературу о Франце Иосифе. Его труд и по сей день остается выдающимся по основательности разработки темы в кругу биографической литературы об австрийском императоре. Рассказывая о встрече в Варшаве, историк пишет: «Франц Иосиф был лишен присущей царю романтической выспренности, однако его все

7 Любезно сообщено Ильдико Рошонци. 
же растрогала любезная доброта старшего друга и покровителя. На большом балконе Лазенковского дворца он поцеловал царю руку».8

В своей книге Андял указал и источник, из которого был взят этот эпизод. Это помещенная в 39 томе (1938) журнала Hadtörténelmi Közlemények рецензия известного слависта Антала Ходинки на книгу советского историка Ребекки Авербух Царская интервенция в борьбе с венгерской революцией: 1848-1849, опубликованную в 1933 г. Однако Ходинка лишь отметил, что Авербух «не упоминает о том, о чем можно прочитать в рецензированных мною [Ходинкой] работах русских авторов, - что Франц Иосиф поцеловал Николаю руку на большом балконе Лазенковского дворца». ${ }^{9}$ Выше в рецензии говорится, что в 1887 г. Алесандр Щербатов в VI томе биографии Ивана Федоровича Паскевича опубликовал письма царя Паскевичу, а также что Ходинка «примерно 40 лет назад» [то есть ок. 1898 г.] тоже ознакомил читателей в своей рецензии «с множеством писем царя Паскевичу, которые были опубликованы в одной русской книге». ${ }^{10}$

Следовательно, Ходинка пишет о трех работах: о VI томе биографии Ивана Федоровича Паскевича, написанной Александром Петровичем Щербатовым, о какой-то неназванной русской книге, в которой были опубликованы письма царя Паскевичу, и, наконец, о собственной рецензии на эту книгу, напечатанной около 1898 г. Однако VI том составленной щербатовым биографии Паскевича, касающийся военных действий в Венгрии, был опубликован не в 1887, а в 1899 г., то есть приблизительно за сорок лет до рецензии Ходинки на книгу Авербух. Возможно еще, что Ходинка писал о другой работе, в которой были опубликованы письма царя Паскевичу, однако в научной литературе нет никакого следа такой работы. В 1899 г. в Budapesti Szemle действительно была опубликована пространная рецензия на книгу щербатова, однако ее автором с инициалами К. Ј. едва ли был Ходинка, а другие рецензии на эту книгу нам не известны.11

8 Angyal dávid, Az ifjú Ferenc József (Budapest: Magyar Történelmi Társulat, é. n.) 100.

9 HodinKA ANTAL, „R. A. Averbuch. Cárszkájá intervencijá v borjbe sz vengerszkoj revoluuciej 1848-1849. Moszkva. 1955", Hadtörténelmi Közlemények, no 39 (1938): 130-131. Целование руки не встречается и в другой книге Авербух: ReVeKKA AVERBUch, A magyar nép szabadságküzdelme 1848-49-ben (Budapest, 1970).

10 HodinKA, „R. A. Averbuch. Cárszkájá intervencijá v borjbe sz vengerszkoj revoluuciej 18481849", 129.

11 В 1899-1900 г. появился словацкий перевод повествовательной части этой книги, в 1948 г. он был опубликован в переводе Ласло Сиклаи: Két emlékirat az 1849. évi cári intervencióról (Budapest, 1948), 39-137. 
После этого остается лишь одна возможность: целование руки упоминается где-то в биографии Паскевича, написанной щербатовым. В 1984 г. ее VIтом увидел свет и в венгерском переводе Эигмонда Геренчера и Тамаша Катона в книжной серии Bibliotheca Historica, которую редактировал Тамаш Катона. Однако в нем о варшавской встрече царя и императора можно прочитать лишь следующее: «Государь приехал в Варшаву 4-го [16-го] мая; пять дней спустя, т. е. 9-го [21-го] мая, приехал в Варшаву австрийский император Франц Иосиф. В это время установлены были главные основания предстоящей кампании как в стратегическом, так и в продовольственном отношениях». Кроме этого, через генерал-адъютанта Берга царь повторил требование, чтобы австрийское правительство очистило Галицию от польских эмигрантов и революционеров, и пока этого не произойдет, русские войска не двинутся. Через несколько дней австрийские власти выполнили это требование..$^{2}$ Таким образом, о целовании руки нигде нет ни слова...

Точнее, все-таки есть, но не в связи со встречей императора и царя. Щербатов пишет, что, по словам очевидцев, фельдмаршал-лейтенант Бернгард Кабога, прибывший в Варшаву в начале мая с написанным 1-го мая письмом австрийского премьер-министра Феликса Шварценберга, просившего о немедленной помощи, «повторил содержание письма на словах, и, встав на колени, поцеловал руку князя Варшавского, со слезами умоляя его „спасти Австрию”; „каждый день, каждый час”, говорил он, „дорог"».13 В посланном позднее донесении Паскевича царю можно прочитать несколько более сдержанную версию: «Граф Кабога настоятельно, со слезами на глазах, просил меня о скорейшей помощи для столицы, как величайшей милости для своего отечества».14

Единственным источником того времени, в котором упоминается о целовании царской руки Францем Иосифом, остается написанное в Дёблинге крупное произведение Иштвана Сечени, названное Арпадом Карои Большой венгерской сатирой (Nagy magyar szatíra). В той части этого произведения, которая была написана 22 мая 1857 г., то есть спустя восемь лет после варшавской встречи, Сечени в образе министра внутренних дел Александра Баха говорит Францу Иосифу следующее:

12 SCSERbatov, Paszkevics Magyarországon, 62.

13 SCSERBATOV, Paszkevics Magyarországon, 57.

14 SCSERBATOV, Paszkevics Magyarországon, 346-348. CM.: RosonCzY ILDIKó, Orosz fegyverekkel Ferenc Józsefért. Tanulmányok I. Miklós 1849-es magyarországi beavatkozásáról (Budapest: Magyar Napló, 2016), 149-150. 
«...так и Ваше Величество, как прекрасный плод прекрасных ветвей, поцеловали руку царя московитов и, будучи тогда еще хитроумным молодым лисом, презабавно одурачили чванливого дряхлого медведя, но позже, когда он вытащил Ваше Величество из уже скопившегося у Вас по горло дегтя, и Ваше Величество быстро выросли из молодого лиса в complet Tiger royal [настоящего королевского тигра], Вам, конечно, даже в голову не пришло поблагодарить теплым словом Вашего друга за эту небольшую Gefälligkeitért [любезность], зато, поступив столь же мудро, Вы доказали свою признательность тем, что wegen höherer Staatsrücksichten [из высших государственных соображений], по моему совету или - что же я говорю! - по моей нижайшей просьбе, заняли Влашскую землю [Валахию] и Молдавию, где мы и останемся, если московиты, англичане, французы и особенно пьемонтисты [пьемонтцы] полностью истребят друг друга под Севастополем intra et extra muros [внутри и вне стен], чего я от всего сердца желал и что, признаюсь, суверенностью anticipáltam [предполагал] в качестве ожидаемого результата».15

Опубликовавший этот текст Арпад Карои не присовокупил к нему никаких замечаний, из чего очевидно, что он и сам не мог ни подтвердить, ни опровергнуть эту историю. Во всяком случае, эпизод, описанный Сечени, может быть истолкован и символически, - Сечени показал поведение императора в качестве параболы подобострастия и вероломства.

После этого возникает вопрос, что же рассказывают источники того времени о варшавской встрече?

Ситуация с русскими источниками особая, поскольку надо принять во внимание, что, как на это указывает и цитата из произведения Сечени, в 1853 г., во время Крымской войны, Франц Иосиф I оставил в серьезной беде своего августейшего союзника, больше того, своим неблагожелательным нейтралитетом и военной оккупацией Дунайских княжеств он только осложнил дело Николаю І. Иначе говоря, если сразу после 1849 года лояльность по отношению к союзнику могла помешать увековечению этого эпизода, то после 1853 года эти соображения уже едва ли имели значение. Однако несмотря на это, насколько

15 Gr. Széchenyi István döblingi irodalmi hagyatéka. II. k. (Budapest: Magyar Történelmi Társulat, 1921), 124. 
нам известно, русские мемуаристы и авторы обобщающих работ не упоминают о целовании руки.

Находившийся при петербургском дворе Теодор фон Бернгарди 22 мая записал в дневнике лишь, что царь не желает подчинять свои войска австрийскому командованию.16 Дмитрий Сонцов, один из адъютантов Паскевича в своих воспоминаниях, написанных в 1850 г., но опубликованных только в 1871 г., пишет о том, что весной 1849 г. у Франца Иосифа, «если он хотел сохранить трон Габсбургов, не оставалось другого выбора, кроме как отправиться в путь и молить Россию о помощи», и он приехал в Варшаву, „чтобы просить царя Николая о спасении». ${ }^{17}$

В крупной обобщающей работе Ивана Ивановича Ореуса о русской интервенции тоже говорится лишь о самом факте встречи в Варшаве, после чего автор переходит к изложению оперативных планов. ${ }^{18}$ Согласно запискам Петра Владимировича Алабина, опубликованным в 1888 г., весной 1849 г. Франц Иосиф «прямо умолял о помощи своего августейшего союзника, усилив самые сердечные свои излияния при варшавском с ним свидании, явившиеся печальным противоречием тому, что вскоре затем последовало».9 В опубликованных в 1889 г. записках адъютанта II русского корпуса А.О. Стренга упоминается лишь факт встречи двух монархов в Варшаве с добавлением того, что тогда стороны условились о деталях русского вмешательства. ${ }^{20}$ Аудитор, генерал-майор Василий Абрамович Докудовский в своих воспоминаниях, напечатанных также в 1889 г, пишет, что 21 мая 1849 г. «явился буквально у стоп его величества [Николая I] и австрийский кайзер-иезуит Франц-Иосиф, которому император Николай на другой же день представил войска, оставшиеся в резерве». ${ }^{21}$ Он же записал анекдот, согласно которому во время варшавской встречи оба

16 V., „Bernhardi emlékiratai”, Budapesti Szemle, no 87 (1896): 284; Unter Nikolaus I. und Friedrich Wilhelm IV. Briefe und Tagebuchblätter aus den Jahren 1834-1857 von Theodor von Bernhardi (Leipzig, 1899), 47. Первое издание - 1893.

17 DMITRIJ Szoncov, „Emlékek a magyarországi hadjáratból. Egy szemtanú és résztvevo feljegyzései", in A magyarországi hadjárat 1849. Orosz szemtanúk a magyar szabadságharcról, szerk. Rosonczy ILDIKó, KATONA TAMÁs (Budapest: Európa Könyvkiadó, 1988), 228.

18 I. I. OREUSz, Oroszország háborúja a magyarok ellen 1849-ben (Budapest: Balassi Kiadó, 2003), 110.

19 P. V. ALABIN, „A magyar háború”, in A magyarországi hadjárat 1849, 47.

20 A. O. SzTRENG, „Háború a magyarok ellen”, in A magyarországi hadjárat 1849, 339.

21 V. A. DokUdovsZKIJ, „Emlékeim”, in A magyarországi hadjárat 1849, 571. 
императора пошли в театр. В антракте Николай I, вставая, уронил стул, но Франц Иосиф не дал стулу упасть и поднял его. «При рассказе об этом случае кто-то сказал, что если Николай поднимает трон австрийский, то Франц Иосиф очень может поднять стул Николаю».22

Как мы видим, русские авторы более или менее чувствовали унизительное положение и угодливость Франца Иосифа, однако они ничего не пишут о целовании руки.

Авторы австрийских работ, появившихся во время правления Франца Иосифа I, тоже ничего не знают об этом эпизоде. В вышедшей в 1865 г. работе Антона Шпрингера говорится лишь о заявлении австрийского правительства от 1 мая и о царском воззвании от 11 мая, но ни словом не упоминается о варшавском свидании. ${ }^{23}$ Согласно обобщающей работе Вальтера Рогге, опубликованной в 1872 г., император встретился в Ungarisch Hradisch-е с наследником русского престола Александром, и затем они вместе отправились в Краков, куда 14 мая, два часа спустя, прибыл и царь. После этого автор излагает воззвание Паскевича, но не пишет о переговорах. ${ }^{24}$

Еще более туманно описание событий у использовавшего и архивные материалы историка Генриха Фридъюнга, которого трудно заподозрить в симпатии к венграм. По его мнению, воспользоваться помощью России, которую предложил и сам царь, Австрию заставила связанность войск Австрийской монархии в Италии. ${ }^{25}$

Не случайно, что, в труде Politikai Magyarország (Венгрия политическая), репрезентирующем то направление исторической науки, которое выступало за независимость Венгрии, Денеш Пазмандимладший посчитал важным подчеркнуть, что «австрийские историки и сейчас не признают этого монаршего визита», и в то же время сам он датировал его 22-24 мая и считал, что два монарха подписали официальный договор, в котором, помимо прочего, содержался и пункт о сохранении венгерской конституции, существовавшей до 1848 г.26

22 V. A. DokUdovszkIJ, „Emlékeim”, 575.

23 Anton SPRINGER, Geschichte Oesterreichs seit dem Wiener Frieden 1809. Zweiter Theil. Die österreichische Revolution (Leipzig, 1865), 732-733.

24 WALter Rogge, Oesterreich von Világos bis zur Gegenwart. Bd. I (Leipzig und Wien), 127.

25 HEINRICH FRIEDJUNG, Österreich von 1848 bis 1860. Erster Band. Die Jahre der Revolution und der Reform 1848 bis 1851 (Stuttgart und Berlin, 1908), 215-216.

26 PÁZMÁNDY DÉNES IFJ., „Az orosz beavatkozás okai és története”, in Politikai Magyarország II. Magyarország története Ferencz császár korától 1910-ig, szerk. SzÁsz JózSEF (Budapest: Anonymos Kiadó, 1913), 152-153, 469, прим. 12. По сообщению Пазманди, он слышал об этом от человека, «который имел возможность читать важные государственные 
А между тем факт встречи двухмонархов был небезызвестен. Сначала в 1851 г. появился русский официальный отчет на немецком языке, под влиянием которого о встрече говорится в работе швейцарского историка Вильгельма Рюстова, которая была опубликована на немецком языке и в венгерском переводе, и на этом основании известие о встрече было включено в критическую обобщающую работу Шаму Серемлеи. ${ }^{27}$ В то же время о встрече не упоминается в выпущеной двумя изданиями, в 1865 г. и после 1867 г., обобщающей работе Михая Хорвата, хотя он и использовал книгу Рюстова. ${ }^{28}$ В венгерской научной литературе о варшавском свидании упоминается в двух работах Генриха Марцали, правда, в одной из них оно датировано 20-м, а в другой 21-м мая. ${ }^{29}$ Текст Рюстова почти дословно позаимствовал Йожеф Брейт в своем обобщающем труде по военной истории, вышедшем в свет впервые в 1898, а позже в 1930 г. ${ }^{30}$ В самой подробной до сего времени биографии императора на венгерском языке, принадлежащей перу Шандора Марки, зафиксирован лишь сам факт варшавской встречи, но, например, в написанной им же, посвященной событиям 1848-49 г. главе десятитомной серии A magyar nemzet története (История венгерской нации), приуроченной к тысячелетию Венгрии, историк не

документы». По мнению автора, договор «помечен 24-м мая по старому календарю», что означало бы 4 июня по грегорианскому календарю. С большой вероятностью здесь может идти речь о подробном договоре, заключенном 10 июня, иначе говоря, факт встречи 21-23 мая смешан с датой заключенного позже письменного договора. O факте варшавской встречи упоминает в том же труде и Янош Ковач: KovÁcs JÁNos, „А magyar szabadságharcz története", in Politikai Magyarország, 122.

$27 \mathrm{H}$ [EINRICH] V[ON] N[EIDHARDT], Bericht über die Kriegsoperationen der russischen Truppen gegen die ungarischen Rebellen im Jahre 1849. Bd. I (Berlin, 1851), 10; WILHELM RüSTOW, Geschichte des ungarischen Insurrectionskrieges in den Jahren 1848 und 1849. Bd. II (Zürich, 1861), 63; WILHELM Rüstow, Az 1848-1849-diki magyar hadjárat története. II. k. (Pest, 1866), 159; SZEREMLEI SAMU, Magyarország krónikája az 1848 és 1849. évi forradalom idejéről. II. $k$. (Pest, 1868), 159.

28 HoRVÁTH MıнÁLY, Magyarország függetlenségi harczának története 1848 és 1849-ben. III. k. (Genf, 1865).

29 MARCZAli HenRIK, A legújabb kor története 1825-1880 (Budapest: Révai Testvérek, 1892), 721; MARCZALI HENRIK, A legújabb kor. III. rész. Korunk állami és társadalmi alkotásai (Budapest: Franklin-Társulat, Révai Testvérek, é. n.), 268.

30 BREIT JózSEF, Magyarország 1848/49. évi függetlenségi harcának katonai története. III. $k$. (Budapest, 1930), 38. (Два издания различаются только версткой текста). 
упомянул о ней. ${ }^{31}$ Не вошел этот эпизод и в пятитомный обобщающий труд Дёрдя Граца. ${ }^{32}$

Конечно, не приходится удивляться молчанию австрийских историков, ведь целование руки, если бы оно действительно имело место, несомненно, выразило бы такое тяжелое унижение, которое ни до, ни после этого не имело прецедента в отношениях между двумя великими державами. Таким образом, с австрийской точки зрения было (было бы) лучше забыть этот эпизод, и вплоть до кончины Франца Иосифа I, последовавшей в 1916 г., едва ли нашелся бы австрийский историк, который описал бы эту историю.

Кажется, не нашел следов этого эпизода и английский автор монографии о царе В. Брюс Линкольн, во всяком случае он не упомянул о нем ни в вышедшей в 1978 г. на английском языке, ни в вышедшей в 1981 г. на немецком языке монографии. ${ }^{33}$ Точно так же молчит об этом эпизоде и автор опубликованной в 1991 г. монографии о русской интервенции Ян В. Робертс, основательно использовавший английские и русские архивные материалы, а также русскую мемуарную литературу. ${ }^{34}$ Из венгерских авторов не знал о поцелуе Лайош Штир, первым использовавший австрийскую оперативную и дипломатическую документацию, правда, в книге, посвященной периоду интервенции, ему «удалось» поначалу датировать с многонедельной ошибкой и само варшавское свидание. ${ }^{35}$

Вопрос в том, что говорится о варшавском свидании в документах того времени. Многие из них известны в настоящее время, в том числе письмо Франца Иосифа I от 21 мая 1849 г., отправленное из Варшавы его матери, принцессе Софии; написанное в тот же день, неполностью изданное письмо Николая I жене и, наконец, помеченные 21-м и 23-м мая донесения английского консула в Варшаве дю Плата.

31 MÁRKI SÁNDOR, I. Ferenc József, Magyarország királya (Budapest: Franklin-Társulat, 1907), 52; MÁRKI SÁNDOR, „Az 1848-49-iki magyar szabadságharc története”, in A magyar nemzet története X. k., szerk. SZILÁGYI SÁNDOR (Budapest: Athenaeum Irodalmi és Nyomdai Részvénytársulat, 1898).

32 GRACZA GYÖRGY, Az 1848-49-iki magyar szabadságharcz története. V. k. (Budapest: Lampel Róbert [Wodianer F. és Fiai], é. $n$ ).

33 W. BRUCE LINCOLN, Nikolaus I. von Rußland 1796-1855 (München: Callwey Verlag, 1981).

34 IAN W. ROBERTS, Nicholas I and the Russian Intervention in Hungary (London: Palgrave Macmillan, 1991), 122-127. DOI: 10.1007/978-1-349-21195-1

35 SteIER LAJOS, Haynau és Paskievics. A szabadságharc revideált története III-IV. rész. I-II. $k$. (Budapest: Genius, é. n), 198. Эта ошибка была исправлена на 310 странице II тома. 
Император в своем письме сообщил о том, что во второй половине дня прибыл в Варшаву, на вокзале его встретил царь, затем они отправились в варшавскую резиденцию наместника, где его разместили вместе с царем. Царь принял его крайне благожелательно и сердечно, в четыре часа дня они отобедали вдвоем. Затем Франц Иосиф перешел к тому, что они очень быстро ехали, и русская железная дорога особенно отличалась порядком, обеспечивая приятное путешествие. «Между прочим, здесь все так хорошо устроено и спокойно, что это идет мне на пользу», - писал император. В заключение он сообщил, что на следующий день будет устроен смотр здешним войскам, из которых он пока видел только одну пехотную роту, но она была великолепна. ${ }^{36}$

В написанном в тот же день письме царь тоже лишь изложил свои впечатления: «Я нашел, что он [Франц Иосиф] крупен и хорошо развит, хотя и не красив, с интересным и приятным лицом; в его чертах видно много спокойствия, некоторая глубина и строгость. Чем чаще я его вижу и слышу, тем больше восхищаюсь его благоразумием, основательностью и благородством понятий. Австрии повезло, что он принадлежит ей». ${ }^{37}$

В донесении министру иностранных дел Пальмерстону от 21 мая консул дю Плат сообщил о том, что появление императора вызвало относительно небольшой интерес, не было больших публичных мероприятий. Царь обращался с императором скорее учтиво, чем сердечно, и это была скорее встреча спасителя и подопечного, чем дружеское свидание двух равноправных сторон. ${ }^{38}$

В донесении от 24 мая консул представил британскому министру иностранных дел уже гораздо более подробный отчет. В нем говорится, что на вокзале царь обнял императора, а затем проводил его в Лазенковский дворец, где уступил ему свои апартаменты. Перед этим царь лично занял место главы почетного караула и приветствовал императора как будто тот был вышестоящим лицом. Для встречи императора появились наместник, князь Паскевич, царская свита,

36 Briefe Kaiser Franz Josephs I. an seine Mutter 1838-1872. Hrsg. und eingeleitet von DR. FRANZ SCHNÜRER (München: J. Kösel \& F. Pustet, 1930), 118.

37 Цитируется по: Theodor Schiemann, Geschichte Russlands unter Kaiser Nikolaus I. Bd. IV. Kaiser Nikolaus vom Höhepunkt seiner Macht bis zum Zusammenbruch im Krimkriege 18401855 (Berlin und Leipzig, 1919) 195. DOI: 10.1515/9783110821536; Примечание 1. В несколько свободном переводе письмо опубликовано в: ANGYAL, Az ifjú Ferenc József, 100.

38 JÁNOSSY DÉNES, „Die russische Intervention in Ungarn im Jahre 1849”, A Bécsi Magyar Történeti Intézet Évkönyve - Jahrbuch des Wiener Ungarischen Historischen Instituts. I. $k$. (Budapest, 1931): 328. Примечание 37. 
высшие офицеры, а также все находившиеся в Королевстве Польском австрийские офицеры. Имератору были представлены только двое - князь Паскевич и граф Орлов; а царю - только премьер-министр Шварценберг и старший адъютант императора граф Карл Грюнне. Во дворце не было канцлера Нессельроде; единственным гражданским лицом, которое участвовало в этом событии, был австрийский консул в Варшаве Валленбург. Несмотря на то, что Грюнне собирался представить Валленбурга и австрийских офицеров императору, тогда представление не состоялось. Вечером было организовано театральное представление и бал, которые император посмотрел из царской ложи.

22 мая состоялся большой парад, на который царь надел венгерский орден Святого Стефана (который в этот раз был вручен и Паскевичу). Царь лично возглавил парадную колонну, саблей приветствовал молодого императора, а потом, стоя рядом с ним с обнаженной и опущенной саблей, смотрел на проходившие мимо части. Сам император в течение всего пребывания в Варшаве носил мундир царской гвардии с орденом Андрея Первозванного. Пока император оставался в Варшаве, русские офицеры, награжденные австрийскими орденами, носили только эти награды.

После этого монархи проследовали в Варшавскую цитадель, где царь обратился к императору с речью, содержание которой дю Плат изложил в частном письме лорду Уестморленду, однако в настоящее время это письмо нам неизвестно. Возвратившись в Лазенковский дворец, император принял австрийского консула Валленбурга, генерала Кабогу, в также группу находившихся в Варшаве австрийских офицеров. Вечером снова были опера и балет; в этот раз в ложе вместе с двумя монархами сидел и Паскевич. Однако, как и предыдущим вечером, отсутствовали канцлер Нессельроде и премьер-министр Шварценберг, они, очевидно, занимались теми делами, ради которых состоялась встреча монархов.

23 мая снова состоялся военный парад, на этот раз своим умением блеснула кавказская мусульманская конница. Дю Плат подчеркнул, что в ходе встречи два монарха, в соответствии с австрийским этикетом, всегда садились за стол вдвоем, хотя царь всегда, особенно находясь в Варшаве, приглашал к столу Паскевича, графа Орлова, генерала Адальберга, а также - не слишком часто - и других высших офицеров. 
23 мая в пять часов пополудни, после обеда, император покинул Варшаву и вернулся в Вену. ${ }^{39}$

Поездка императора проходила в атмосфере строгой секретности - 20 мая генерал-лейтенант Иоганн Кемпен фон Фихтенштамм, глава Пожоньского императорского королевского военного округа, записал в дневнике новость, что 19 мая Николай I прибыл в Варшаву, и Франц Иосиф, прошлым днем покинувший Вену, присоединится к нему 21 мая во второй половине дня. ${ }^{40}$

19 мая бывший председатель Дворцовой палаты Карл Фридрих Кюбек записал новость об отьезде императора с замечанием, что, как говорят, он направился в Варшаву. 25 мая Кюбек писал о возвращении императора, добавив к этому, что премьер-министр Шварценберг во время пребывания в Варшаве получил орден Александра Невского. ${ }^{41}$

22 мая папский нунций Микеле Виала-Прела оповестил кардинала Антонелли о том, что три дня назад император уехал в Ольмюц навестить свою мать, принцессу Софью. Поскольку царь находится в Варшаве, император, возможно, поедет к нему. Его сопровождает премьер-министр Шварценберг. ${ }^{42} 25$ мая испанский поверенный в делах герцог Гор доносил, что днем раньше император вернулся из Варшавы, и что «его встреча с царем Николаем в этом городе была необычайно сердечной и теплой», они все время были вместе и осмотрели размещенные в городе войска. ${ }^{43}$ Бельгийский посол О'Сюлливан де Грас тоже сообщил 26 мая 1849 г. своему правительству только о сердечном приеме, оказанном царем императору.44

39 Цитруется по: Schiemann, Geschichte Russlands unter Kaiser Nikolaus I, 397-398. Интересным (или как раз не слишком интересным) образом соответствующие донесения дю Плата не вошли в «Синюю книгу», составленную британским министром иностранных дел лордом Генри Джоном Темплом Пальмерстоном. Correspondence Relative to the Affairs of Hungary 1847-49; presented to Both Houses of Parliament by Command of Her Majesty, 15 August 1850 (London, 1851).

40 Das Tagebuch des Polizeiministers Kempen von 1848-1859 (Wien und Leipzig: Österreichischer bundesverlag für unterricht, wissenschaft und kunst, 1931), 136.

41 Aus dem Nachlass des Freiherrn Carl Friedrich Kübeck von Kübau. Tagebücher, Briefe, Aktenstücke (1841-1855) (Graz-Köln: H. Böhlaus Nachf, 1960), 28.

42 LUKÁCS LAJOS, The Vatican and Hungary 1846-1878. Reports and Correspondence on Hungary of the Apostolic Nuncios in Vienna (Budapest: Akadémiai Kiadó, 1981), 337-338.

43 Anderle ÁdÁm (szerk.), A magyar kérdés. Spanyol követi jelentések Bécsből 1848-1868 (Szeged: Hispánia Kiadó, 2002), 59.

44 Цитируется по ERDŐDY GÁBOR, A demokrácia katonái. A magyarországi polgárialkotmányos átalakulás és szabadságharc belga megítélése 1848-1849-ben, (Budapest: ELTE Eötvös, 2010), 118-119. 
Для полноты картины надо добавить, что в ходе встречи два монарха и сопровождавшие их политики и военные вели переговоры не только о действиях против венгров, речь шла и о потенциальном объединении Германии, в том числе о вопросах, связанных с прусскими проектами унии, а также о все еще продолжавшейся датско-немецкой войне и связанном с ней шлезвиг-гольштейнском конфликте.

В целом ни один из современных упомянутым событиям, да и позднейших источников не подтверждает легенду о целовании руки. (Отрывок из произведения Сечени не может считаться достоверным источником). Представляется, что мы имеем дело с возникшей в двадцатом веке и распространившейся только в венгерской специальной литературе легендой, которая берет начало в неточно сформулированной рецензии Антала Ходинки. Затем Давид Андял не только не проверил содержавшееся в этой рецензии упоминание о целовании руки, но к тому же еще неправильно понял его. Характерная для личности и работ Андяла точность, проявлявшаяся во всех других отношениях, придала достоверность и этому его утверждению.

Отсюда его позаимствовал в 1948 г. Ференц Экхарт, включивщий его в свою обобщающую работу 1848, a szabadság éve (1848, год свободы),45 а из нее оно позже попало сначала в написанную Дёрдем Шпира главу университетскогоучебника, апотомв написанную им и опубликованную в 1959 г. книгу A magyar forradalom 1848-49-ben (Венгерская революция 1848-49)..$^{46}$ Этот перечень может быть продолжен, ${ }^{47}-$ к сожалению, я и

45 ECKHART FERENC, 1848, a szabadság éve (Budapest: Káldor György Könyvkiadóvállalat, 1948), 240-241.

46 SPIRA GYÖRGY, A magyar forradalom 1848-49-ben (Budapest: Gondolat Könyvkiadó, 1959), 529; SPIRA GYÖRGY, „Polgári forradalom és nemzeti szabadságharc 1848-1849”, in Magyarország története 1790-1849. A feudalizmusról a kapitalizmusra való átmenet korszaka. Magyarország története III., szerk. MÉREI GYULA, SPIRA GYÖRGY (Budapest: Tankönyvkiadó Vállalat, 1975), 177; SPIRA GYöRGY, A pestiek Petöfi és Haynau között (Budapest: Enciklopédia Kiadó, 1998), 559. (Здесь он ссылается на протицированный выше текст Сечени). SPIRA GYÖRGY, „Mit ünnepelünk május 21-én?”, in Ünnep - hétköznap - emlékezet. Társadalom- és kultúrtörténet határmezsgyéjén. A Hajnal István Kör Társadalomtörténeti Egyesület konferenciája Szécsény, 2000. augusztus 24-26., szerk. PÁszTOR CéílıA (Salgótarján: Nógrád Megyei Levéltár, 2002), 285-289.

47 Не претендуя на полноту перечня: VARGA JÁNOS, „Az 1848-1849-i polgári forradalom és szabadságharc", in Magyarország története, föszerk. MoLnÁR ERIK, szerk. PAMLÉNYI ERVIN és SZÉKELY GYöRGY. I. k. (Budapest: Gondolat Kiadó, 1964). (2-е, отчасти переработанное издание: Budapest: Gondolat Kiadó, 1967), 546; SomogYI ÉvA, Ferenc József (Budapest: Gondolat Kiadó, 1989), 35; STEFAN KováTS, „Az 1849. évi orosz katonai intervenció Magyarországon. A magyar forradalom és szabadságharc az európai nagyhatalmi érdekek középpontjában", Századok 125, no. 3-4 (1991): 286; DEÁK ISTVÁN, A törvényes 
сам принадлежал к многочисленному лагерю «перепевщиков»... ${ }^{48}$ В то же время никому не бросилось в глаза, что следов этого эпизода нет не только в австрийской специальной литературе, ${ }^{49}-4 т о$, конечно было бы вовсе не удивительно,,$^{50}$ - но и в книге Яна В. Робертса, наиболее основательно разработавшего тему русской интервенции и использовавшего неизданные дипломатические донесения.

Писатели тоже внесли свой вклад в распространение этой истории. Мотив целования руки был включен в киноновеллу Дюлы Ийеша Két férfi (Двое мужчин), написанную в 1950 г. (ее сильно переработанный и выхолощенный вариант послужил сценарием для фильма Föltámadott a tenger / Восстало море/)51, а также в драму Fáklyaláng (Пламя факела), премьера которой состоялась в 1952 г.

forradalom. Kossuth Lajos és a magyarok 1848-49-ben (Budapest: Gondolat Kiadó, 1994), 304. (Первая публикация на английском языке: New York: Columbia University Press, 1981); VADÁSZ SÁNDOR (szerk.), Az 1849-es cári intervenció Magyarországon (Budapest: Korona Kiadó, 2001), 11-12; GERő ANDRÁs, Ferenc József és a magyarok (Budapest: KKETTK Közalapítvány, 2016), 70-71. (Первое издание: Budapest: Novotrade, 1988). К числу исключений принадлежит крупная обобщающая работа Домокоша Кошари по истории внешней политики, в которой вообще не упоминается варшавское свидание: KOSÁRY DomoKos, Magyarország és a nemzetközi politika 1848-1849ben (Budapest: MTA Történettudományi Intézet, 1999). С некоторой осторожностью считает возможным целование руки: PELYACH ISTVÁN, „Egy legenda nyomában. Vécsey Károly gróf kézcsókja az akasztófa árnyékában", Aetas, 28, no. 2 (2013): 107-108.

48 HERMANN RóbeRT, 1848-1849. A szabadságharc hadtörténete (Budapest: Korona Kiadó, 2001), 411; HERMANN RóBERT, Az 1848-1849-es szabadságharc nagy csatái (Budapest: Zrínyi Kiadó, 2004), 258.

49 Напр., в посвященной варшавской встрече части самой основательной биографии австрийского императора. EGON CAESAR CONTE CORTI, Mensch und Herrscher. Wege und Schicksale Kaiser Franz Josephs I. zwischen Tronbesteigung und Berliner Kongreß (GrazSalzburg-Wien: Verlag Styria, 1952), 30-31. Не знает о нем и автор самой основательной биографии Шварценберга. STEFAN LIPPERT, Felix Fürst zu Schwarzenberg. Eine politische Biographie (Stuttgart: Franz Steiner Verlag, 1998), 254-255.

50 В то же время очень поучительно, что о варшавской встрече Франца Иосифа I и Николая I не упоминается и в вышедшей к столетней годовщине и в принципе свободной от габсбургских реминисценций крупной австрийской обобщающей работе. Rudolf Kiszling, Die Revolution im Kaisertum Österreich 1848-1849. Bd. II (Wien: Universum, 1948). В жизнеописании Феликса Шварценберга Кислинг уже кратко касается варшавской встречи, но и он ничего не знает о целовании руки. RUdolF KISzLING, Fürst Felix zu Schwarzenberg. Der politische Lehrmeister Kaiser Franz Josephs (Graz-Köln: Herman Böhlaus Nachf., 1952), 94-95.

51 ILLYÉS GYULA, „Két férfi”, in Föltámadott a tenger... Az 1848-49-i forradalom és szabadságharc irodalmából, szerk. LUKÁCSY SÁNDOR (Budapest: Kozmos Könyvek, 1976), 433. 
И при этом никто не обратил внимания на то, что обо всем этом ничего не известно ни австрийским, ни русским специалистам. И это опятьтаки показывает, что иногда невредно заметить, что известно (или не известно) в международной специальной литературе о считающемся важным, более того, эмблематичным событии. ${ }^{52}$

Это невредно уже потому, что, если даже легенда о целовании руки вымысел, суть дела от этого не меняется. Ведь император и австрийское правительство все же вынуждены были унизиться перед царем, и в результате произошло небывалое во всемирной истории событие, когда великая держава вынуждена была молить о помощи, чтобы подавить «внутренний бунт». И это было серьезным признанием успехов венгерских гонведов, даже несмотря на то, что венгерская армия в итоге потерпела поражение в столкновении с многократно превосходящими силами русских и австрийцев.

52 См. то же самое явление в связи с фиктивным рапортом фельдмаршала Альфреда цу Виндишгреца о битве при Каполне. HERMANN RóBERT, „Lázadó csordák - oktrojált alkotmány - egy legenda nyomában", in Reformkor, forradalom, szabadságharc (Budapest: Line Design, 2016), 207-230. 
